\title{
RELASI GENDER DALAM KELUARGA PEREMPUAN OJEK-ONLINE DI SURAKARTA \\ (Studi Deskriptif Pada Keluarga Perempuan Ojek-Online Go-Jek di Surakarta)
}

\author{
Devi Yulianita Victorine B.Q ${ }^{1}$, Thomas Aquinas Gutama ${ }^{2}$ \\ Program Studi Sosiologi Fakultas Ilmu Sosial dan Politik \\ Universitas Sebelas Maret Surakarta Indonesia \\ Email$^{1}$ : devivictorine@gmail.com,Email²: thomasaquinas@staff.uns.ac.id
}

\begin{abstract}
This research aims to determine the activities division, access-control distribution, and the factors that influence the division of activities and access-control in the families of women-online taxibikers "Go-Jek" in Surakarta. Talcott Parsons' Structural Functionalism theory is used in this research. This is a qualitative descriptive research. The data were collected from indepth interview, observation, and documentation. The subjects were the families of women-online taxibikers "Gojek in Surakarta. The researcher used source triangulation to examine the validity of the data. In analyzing the data, the researcher used Miles and Huberman's theory which consisted of data reduction, data presentation, and drawing conclusion. In addition, Harvard's analysis technique was also used to observe the gender's profile within a family.

The results show that there are division of activities in the families of women-online taxibikers. The production activities in those families are carried out together, both husband and wife work together to earn a living. It proves that there are equal opportunities for the husband and wife in carrying out production activities. Whereas in reproductive activities, even though there is already a husband's involvement, the wife has more dominant role. In social activities, there are activities-differentiation for husband and wife although they are both involved in community activities. Men's activities are still regarded to be publicoriented, while women's activities are still related to reproductive matters. Regarding the access-control division, it is now done by the woman or wife more oftenly. The factors that influence the distribution of activities and access control in the families of women-online taxibikers "Go-Jek" are economic, cultural, and educational factors. It can be concluded that gender relations in the families of women-online taxibikers "Go-Jek" in Surakarta have complementary relationships. Although there are some differences in roles, they have the same goal, namely family harmony.
\end{abstract}

Keywords : gender relation, family, woman

Abstrak: Penelitian ini bertujuan untuk mengetahui pembagian aktivitas, pembagian akseskontrol, dan faktor-faktor yang mempengaruhi pembagian aktivitas dan akses-kontrol di dalam keluarga perempuan ojek-online Go-Jek di Surakarta. Teori yang digunakan dalam penelitian ini adalah teori Struktural Fungsional oleh Talcott Parsons. Jenis penelitian ini adalah kualitatif dengan menggunakan pendekatan deskriptif. Data didapatkan melalui wawancara mendalam, observasi, dan dokumentasi. Subyek penelitian ini adalah keluarga perempuan ojek-online Go-Jek di Surakarta. Untuk menguji keabsahan data yang telah terkumpul, peneliti menggunakan teknik triangulasi sumber. Dalam analisa data, peneliti mengunakan pandangan Miles dan Huberman yang terdiri dari tiga alur kegiatan, yaitu reduksi data, penyajian data, dan menarik kesimpulan. Yang kedua peneliti menggunakan 
teknik analisa Harvard. Teknik analisa Harvard digunakan untuk melihat profil gender pada suatu keluarga.

Hasil penelitian menunjukkan bahwa terdapat adanya pembagian aktivitas di dalam keluarga perempuan ojek online. Aktivitas produksi di dalam keluarga perempuan ojek online dilakukan bersama-sama, baik suami maupun istri sama-sama bekerja untuk memperoleh pendapatan keluarga. Ini membuktikan bahwa di antara suami dan istri terdapat adanya kesempatan yang sama dalam melakukan aktivitas produksi. Sedangkan pada aktivitas reproduksi, meskipun sudah ada keterlibatan suami, aktivitas reproduksi ini lebih dominan dilakukan oleh istri. Dalam kegiatan sosial kemasyarakatan, meskipun suami dan istri samasama terlibat dalam kegiatan masyarakat, terdapat pembedaan antara aktivitas suami dan istri. Aktivitas laki-laki masih dianggap sebagai aktivitas yang berorientasi pada ranah publik, sedangkan aktivitas perempuan masih berkaitan pada hal-hal reproduktif. Mengenai pembagian akses kontrol di dalam keluarga perempuan ojek online Go-Jek, kini akses-kontrol lebih banyak dilakukan oleh perempuan atau istri. Faktor-faktor yang mempengaruhi pembagian aktivitas dan akses kontrol pada keluarga perempuan ojek online Go-Jek ialah faktor ekonomi, faktor budaya, dan faktor pendidikan. Dapat disimpulkan bahwa relasi gender di dalam keluarga perempuan ojek-online Go-Jek di Surakarta terdapat adanya hubungan yang saling melengkapi. Meskipun terdapat beberapa perbedaan peran tetapi memiliki tujuan yang sama, yaitu keharmonisan keluarga.

Kata Kunci: relasi gender, keluarga, perempuan.

\section{PENDAHULUAN}

Permasalahan mengenai relasi gender, ketimpangan gender, kesetaraan gender selalu menarik untuk dibicarakan. Permasalahan tersebut selalu mendapat perhatian baik dari penentu kebijakan, akademisi maupun aktivis-aktivis lain pembela kaum minoritas. Bentuk perhatian tersebut bermacam-macam, seperti persoalan pembagian kerja antara laki-laki dan perempuan, persoalan akses-kontrol perempuan, perempuan dalam ruang publik maupun privat, beban kerja dan perempuan dalam pembangunan. Sehingga penting untuk meningkatkan kesetaraan gender baik dalam kehidupan keluarga maupun masyarakat.

Pembagian kerja di dalam keluarga merupakan fokus dalam penelitian ini. Konstruksi yang ada di masyarakat bahwa pembagian kerja antara laki-laki dan perempuan dalam keluarga didasarkan pada jenis kelamin, yaitu laki-laki bekerja sebagai pencari nafkah dan beraktivitas keluar rumah, sedangkan perempuan bekerja sebagai ibu rumah tangga dan beraktivitas di dalam rumah. Di Indonesia, juga diatur dalam Undang-Undang Perkawinan No.1 tahun 1974 pasal 31 ayat (3) yang secara tegas menyebutkan bahwa suami sebagai kepala keluarga dan istri sebagai ibu rumah tangga, serta pasal 34, suami wajib melindungi istri dan istri wajib mengatur rumah tangga sebaik-baiknya. Pernyataan dalam undangundang tersebut bila ditelaah terdapat bias gender antara laki-laki dan perempuan yang memposisikan perempuan untuk lebih berperan pada sektor domestik.

Dalam kultur masyarakat Jawa, perempuan selalu diidentikkan sebagai konco wingking. Konsep konco wingking berhubungan langsung dengan perempuan dalam rumah tangga. Perempuan mempunyai dua peran yakni sebagai ibu pendidik anak dan sebagai istri yang harus memperhatikan kebutuhan suami sekaligus kebutuhan rumah tangga. Peran inilah yang memunculkan istilah konco wingking (teman belakang) (Kartodirdjo dkk, 1982: 192). 
Pembagian kerja ini sebenarnya tidak menjadi masalah, namun yang perlu dipermasalahkan adalah bagaimana posisi masing-masing dalam hubungan kerjanya dan bagaimana memberikan nilai terhadap prestasi kerja masing-masing. Dalam sebuah keluarga manakala perempuan hanya terlibat dalam kegiatan reproduksi maka akses ke sumber daya keluarga lebih banyak dinikmati oleh laki-laki (Argyo, 2007). Namun, pembagian kerja berdasarkan seksual tersebut mulai bergeser ketika perempuan ikut serta dalam aktivitas mencari nafkah dikarenakan terdesak untuk mencukupi kebutuhan ekonomi keluarga. Ketika perempuan keluar dari rumah untuk bekerja maka hal ini merupakan sebuah aktivitas yang bersifat ekonomis atau dalam arti lain bekerja untuk menghasilkan uang (Abdullah, 2001: 104).

Menurut data BPS Tingkat Partisipasi Angkatan Kerja (TPAK) perempuan pada tahun 2018 sebesar 51,88\%. Presentase tersebut masih dibawah dibandingkan dengan Tingkat Partisipasi Angkatan Kerja (TPAK) laki-laki, yaitu sebesar 82,69\%. Angka ini meningkat sebesar $0,40 \%$ dari tahun lalu. Sehingga dapat dikatakan bahwa keikutsertaan perempuan yang bekerja di sektor publik semakin meningkat jumlahnya. Selain itu, berdasarkan hasil pengukuran IPG (Indeks Pembangunan Gender) 2018 antar kota/kabupaten di Jawa Tengah, Kota Surakarta menduduki peringkat pertama yaitu sebesar 96.82, meningkat 0,08 dari tahun 2017. Hasil pengukuran tersebut mengindikasikan semakin kecil kesenjangan pembangunan antara laki-laki dan perempuan. Sehingga, hal ini menunjukkan bahwa perempuan semakin menunjukkan perannya dalam pembangunan, melalui keterlibatan dan peran aktif perempuan dalam bidang ekonomi.

Keikutsertaan perempuan yang bekerja di sektor publik semakin meningkat jumlahnya. Demikian yang terjadi pada perempuan ojek online, perempuan-perempuan mulai ikut berperan menekuni pekerjaan-pekerjaan yang didominasi oleh laki-laki. Oleh karena itu masuknya perempuan ke sektor ekonomi di ranah publik sedikit banyak membuat perubahan berbagai hal dalam kehidupan perempuan. Dengan kata lain perempuan juga ikut mencari penghasilan yang secara kultural digariskan sebagai kewajiban atau pekerjaan laki-laki. Dalam konteks keluarga menarik untuk melihat bagaimana relasi gender yang terjadi antara laki-laki dan perempuan setelah terlibatnya perempuan di sektor ekonomi publik. Dalam sebuah keluarga, perempuan tidak lagi hanya mengurusi urusan rumah tangga tetapi juga sebagai penghasil ekonomi dalam keluarga.

Berdasarkan paparan di atas, kiranya menarik untuk mengkaji tentang relasi gender di dalam keluarga. Oleh karena itu peneliti ingin melakukan penelitian berjudul "Relasi Gender dalam Keluarga Perempuan Ojek-Online di Surakarta". Dalam hal ini peneliti ingin mengetahui dan mendeskripsikan mengenai pembagian aktivitas, akses dan kontrol yang terjadi antara suami dan istri di dalam sebuah keluarga, yang mana dalam keluarga tersebut seorang istri telah bekerja sebagai ojek online Go-Jek di Surakarta.

\section{Relasi Gender}

Gender adalah pembedaan antara perempuan dan laki-laki dalam peran, fungsi, hak, perilaku yang dibentuk oleh ketentuan sosial dan budaya setempat (Nugroho, 2008: 4). Relasi gender mempersoalkan posisi perempuan dan laki-laki dalam pembagian sumberdaya dan tanggungjawab, manfaat, hak-hak, kekuasaan dan previlese. Penggunaan relasi gender sebagai suatu kategori analisis tidak lagi berfokus pada perempuan yang dilihat terisolasi dari laki-laki (Nugroho, 2008: 238). Pada penelitian ini dimaksudkan untuk melihat relasi yang terjadi pada keluarga perempuan yang ojek-online Go-Jek di Surakarta. Relasi tersebut diwujudkan dalam pembagian aktivitas, akses dan kontrol antara perempuan dan laki-laki di dalam keluarga. 


\section{Pembagian Kerja Keluarga}

Keluarga dapat didefinisikan sebagai suatu kelompok dari orang-orang yang disatukan oleh ikatan-ikatan perkawinan, darah, atau adopsi; merupakan rumah tangga sendiri; berinteraksi dan berkomunikasi satu sama lain yang menimbulkan peranan-peranan sosial bagi suami isteri, ayah dan ibu, putra dan putri, saudara laki-laki dan perempuan; dan merupakan pemelihara kebudayaan bersama (Khairuddin, 1997: 7). Menurut Levy bahwa tanpa ada pembagian tugas yang jelas pada masing-masing aktor dengan status sosialnya, maka fungsi keluarga akan terganggu yang selanjutnya akan mempengaruhi sistem yang lebih besar lagi.

Pembagian kerja dalam sebuah keluarga juga dapat dilakukan dengan berbagai cara. Dalam penelitian ini, pekerjaan atau kegiatan tersebut dibagi menjadi tiga kelompok:

a) Pekerjaan atau kegiatan produktif

Yaitu kegiatan yang dilakukan anggota keluarga dalam rangka mencari nafkah. Kegiatan ini disebut juga kegiatan ekonomi karena kegiatan ini menghasilkan uang

b) Pekerjaan atau kegiatan reproduktif Yaitu kegiatan yang berhubungan erat dengan pemeliharaan dan pengembangan sumber daya manusia yang ada dalam keluarga. Kegiatan ini tidak menghasilkan uang secara langsung.

c) Pekerjaan atau kegiatan sosial budaya

Yaitu kegiatan yang dilakukan anggota keluarga berhubungan dengan politik, sosial, dan budaya (Argyo, 2007: 29).

Perempuan bekerja (employed women) adalah perempuan yang bekerja untuk mendapatkan upah (Matlin, 2004). Keterlibatan wanita dalam pasar tenaga kerja merupakan pengaruh dari:

1. Faktor ekstern yang merupakan faktor penarik untuk bekerja yakni adanya kesempatan kerja yang ditawarkan oleh kapitalis.

2. Faktor intern, yang merupakan faktor pendorong untuk bekerja yakni desakan/kesulitan ekonomi keluarga (Sudarwati, 2003).

Ojek online merupakan angkutan umum yang sama dengan ojek pada umumnya, yang menggunakan sepeda motor sebagai sarana pengangkutan namun ojek online dapat dikatakan lebih maju karena telah terintegrasi dengan kemajuan teknologi. Ojek online merupakan ojek sepeda motor yang menggunakan teknologi dengan memanfaatkan aplikasi pada smartphone yang memudahkan pengguna jasa untuk memanggil pengemudi ojek. Pelayanan ojek online tidak hanya dalam hal sebagai sarana pengangkutan orang dan/atau barang namun juga dapat dimanfaatkan untuk membeli barang bahkan memesan makanan (suduthukum.com).

\section{METODE PENELITIAN}

Dalam penelitian ini, peneliti menggunakan pendekatan dan jenis penelitian deskriptif kualitatif. Lokasi penelitian ini dilaksanakan di Surakarta, dalam hal ini pada keluarga perempuan ojek online atau rumah perempuan yang bekerja di Kantor PT Go-Jek. Data didapatkan melalui wawancara mendalam, observasi, dan dokumentasi. Subyek penelitian ini adalah keluarga perempuan ojek-online Go-Jek di Surakarta. Untuk menguji keabsahan data yang telah terkumpul, peneliti menggunakan teknik triangulasi sumber. Dalam analisa data, peneliti mengunakan pandangan Miles dan Huberman yang terdiri dari tiga alur kegiatan, yaitu reduksi data, penyajian data, dan menarik kesimpulan. Yang kedua peneliti 
menggunakan teknik analisa Harvard. Teknik analisa Harvard digunakan untuk melihat profil gender pada suatu keluarga.

\section{HASIL DAN PEMBAHASAN}

Hasil penelitian tentang relasi gender pada keluarga perempuan ojek online Go-Jek di Surakarta ini dikelompokkan menjadi tiga bagian utama. Pertama, pembagian aktivitas, yang terdiri dari aktivitas produksi, aktivitas reproduksi dan kegiatan sosial kemasyarakatan. Kedua, pembagian akses dan kontrol, yang terdiri dari akses dan kontrol terhadap sumberdaya dan manfaat. Dan ketiga adalah faktor-faktor yang berpengaruh. Pada profil aktivitas ini menampilkan seluruh aktivitas atau tugas yang dilakukan oleh keluarga perempuan ojek online Go-Jek baik suami, istri dan anak. Aktivitas tersebut meliputi aktivitas produksi, aktivitas reproduksi dan kegiatan sosial kemasyarakatan.

\section{Pembagian Aktivitas Produksi}

Aktivitas produksi merupakan kegiatan ekonomi yang dilakukan seseorang untuk memperoleh pendapatan, sehingga pendapatan tersebut dapat digunakan untuk memenuhi kebutuhan manusia dan menjaga keberlangsungan hidup. Aktivitas inilah yang umumnya dipahami sebagai "bekerja" oleh orang per orang maupun oleh masyarakat. Mengenai aktivitas produksi bahwa dalam keluarga perempuan ojek online tersebut pembagian aktivitas produksi dilakukan bersama-sama. Baik suami maupun istri sama-sama bekerja dan saling bekerjasama untuk memperoleh pendapatan keluarga. Pekerjaan yang ditekuni suami mereka antara lain karyawan mebel, tukang pijat, driver di bank, satgas di Go-jek dan tukang laundry. Sedangkan istri juga terlibat dalam aktivitas produksi yaitu dengan menekuni pekerjaan mereka sebagai ojek online di Go-Jek. Ini membuktikan bahwa adanya kesempatan yang sama dalam hal aktivitas produksi karena keduanya baik suami maupun istri sama-sama melakukan aktivitas tersebut untuk memperoleh penghasilan di dalam keluarga. Meskipun demikian, penghasilan yang diperoleh oleh perempuan selalu didefinisikan sebagai penghasilan tambahan, dan bukan yang utama. Hal ini karena peran kultural mendefinisikan laki-laki sebagai pencari nafkah utama sehingga walaupun perempuan bekerja maka dia tidak dianggap sebagai pencari nafkah, namun hanya membantu suami mencari nafkah.

Adanya term penghasil utama dan penghasil tambahan tersebut dapat dikatakan bahwa terdapat diferensiasi peran antara suami dan istri yang berbeda dalam kehidupan keluarga. Suami dikonotasikan sebagai penghasil utama karena suami mengidentifikasikan dirinya sebagai pencari nafkah atau yang bertanggungjawab terhadap keluarga, sedangkan istri mengidentifikasikan dirinya sebagai ibu rumah tangga. Ketika istri ingin membantu suami untuk mencari nafkah diperbolehkan, namun bukan yang utama. Akibatnya, perempuan kurang bekerja secara maksimal atau dalam hal ini hanya paruh waktu. Berbeda dengan laki-laki yang mampu bekerja secara maksimal atau dalam hal ini bekerja penuh dalam sehari. Hal tersebut dilakukan karena kedua belah pihak memiliki komitmen bersama dan menghormati peran masing-masing.

Meskipun suami dan istri memiliki profesi masing-masing, namun terdapat juga salah satu pekerjaan yang dikerjakan bersama-sama atau saling membantu salah satu pekerjaan baik pekerjaan istri maupun suami. Dalam hal ini suami ikut menemani istri dalam melakukan pekerjaan istri, seperti mengantar orderan Go-Food pada saat malam hari. Hal ini dilakukan karena adanya kekhawatiran terhadap istri yang bekerja hingga malam demi mendapatkan penghasilan dari bekerja sebagai ojek online. Pada situasi tersebut perempuan yang harusnya mampu bekerja hingga malam namun tetap menyadari bahwa perempuan 
rawan terhadap gangguan pada saat malam hari. Sehingga mereka tetap membutuhkan sosok lelaki atau suami yang melindunginya. Perlindungan tersebut dilakukan untuk menghindari kemungkinan terhadap pelecehan seksual, pembegalan maupun perampokan. Begitu pula dengan pekerjaan suami, yang juga dibantu oleh istri. Seperti misalnya dalam usaha laundry. Terdapat pembagian tugas di dalam usaha laundry tersebut, yaitu suami bertugas mencuci dan antar jemput laundryan sedangkan istri bertugas menyetrika dan menerima pesanan melalui online atau whatsapp. Sehingga dapat dikatakan bahwa mereka baik istri maupun suami saling membantu dalam menjalankan pekerjaan mereka yaitu sebagai ojek online dan membantu pekerjaan suami.

Keterlibatan istri dalam aktivitas produksi juga meneguhkan bahwa istri yang sebelumnya memposisikan diri sebagai ibu rumah tangga tetapi juga dapat berperan aktif dalam aktivitas produksi. Istri yang ikut terlibat dalam aktivitas produksi, selain didasarkan pada faktor ekonomi juga sebagai bentuk kemandirian istri dan tidak ingin bergantung kepada suami. Hal tersebut dilakukan karena sebelumnya mereka merasa bergantung pada suami mengenai kebutuhan ekonomi, sehingga membuat istri tidak bebas dalam mengakses pendapatan keluarga sebelumnya. Oleh karenanya, bekerja sebagai pengemudi Go-Jek diharapkan dapat menjadikan perempuan mandiri, yaitu dengan memperoleh penghasilan sendiri. Dengan diperolehnya penghasilan sendiri kini para istri tersebut juga bebas memanfaatkan penghasilan mereka untuk keperluan pribadi mereka sendiri. Seperti kebutuhan ke salon, biaya kecantikan, berbelanja pakaian dan berbagai kebutuhan kesenangan lainnya. Para suami tidak mengontrol pengeluaran istri karena mereka berpikiran bahwa uang yang digunakan merupakan penghasilan istri sendiri. Bahkan suami tetap memberikan pendapatannya kepada istri meskipun istri sudah memiliki pendapatan sendiri.

\section{Pembagian Aktivitas Reproduksi}

Aktivitas reproduksi merupakan kegiatan yang dilakukan di dalam rumah tangga, yang berkenaan dengan perawatan dan pemeliharaan dalam upaya untuk menjaga kelangsungsungan hidup rumah tangga. Aktivitas tersebut meliputi: memasak, mengasuh dan mendidik anak, menyapu, mengepel, membersihkan kamar mandi, mencuci, menyetrika, menyediakan air, mengurus listrik, berbelanja ke pasar. Pada kegiatan reproduksi terdapat adanya pembagian kerja antara suami dan istri. Kegiatan reproduksi tidak hanya dilakukan oleh istri saja, tetapi juga suami. Kegiatan reproduksi yang dilakukan istri rata-rata antara lain kegiatan memasak, mengasuh anak, menyapu, mencuci, menyetrika dan berbelanja ke pasar. Kegiatan tersebut dilakukan karena adanya anggapan bahwa pekerjaan tersebut merupakan kewajiban bagi istri. Sedangkan kegiatan reproduksi yang dilakukan laki-laki antara lain mengepel, membersihkan kamar mandi, menyediakan air, mengurus listrik. Meskipun demikian, terkadang juga terdapat adanya tukar peran mengenai pekerjaan reproduksi tersebut antara suami dan istri sesuai dengan kesibukan masing-masing.

Namun, meskipun sudah ada partisipasi laki-laki, kegiatan reproduksi ini lebih dominan dilakukan oleh istri, selain berperan dalam kegiatan produksi. Hal tersebut karena pekerjaan istri yang lebih fleksibel dibandingkan pekerjaan suami. Selain itu kegiatan reproduksi dilakukan istri karena ia menganggap bahwa dirinya sebagai ibu rumah tangga. Istri yang mengidentifikasikan dirinya sebagai ibu rumah tangga menganggap kegiatan reproduksi menjadi tanggungjawabnya. Hal tersebut disebabkan adanya anggapan bahwa kegiatan reproduksi merupakan "pekerjaan perempuan" mengakibatkan banyak perempuan yang sejak dini telah disosialisasikan untuk menekuni peran gender mereka.

Meskipun baik istri dan suami sama-sama menyadari bahwa tanggung jawab terhadap reproduksi merupakan tanggungjawab keduanya, namun istri lebih memilih mengorbankan 
pekerjaannya. Dalam hal ini lebih memilih mengalah untuk tidak bekerja sampai malam, karena merasa kegiatan reproduksi seperti mengasuh anak tidak bisa ditinggalkkan. Sebenarnya istri bisa saja bekerja hingga malam, dan hal tersebut juga tidak dilarang oleh suaminya. Namun istri lebih menekan ego untuk bekerja hingga malam atau mengejar materi, dan lebih memilih mengurus anak di rumah. Hal tersebut atas dasar kemauan sendiri, bukan karena perintah dari suami. Sehingga dapat terjadi keseimbangan antara kegiatan produksi dan kegiatan reproduksi. Hal ini membuktikan bahwa sifat keibuan masih melekat pada ibu yang bekerja, dengan mau mengalah dan berkorban demi memprioritaskan keluarga. Bagi mereka pekerjaan tidak membatasi mereka untuk bertanggungjawab dalam pengasuhan keluarga. Sehingga, selain istri berperan dalam kegiatan produksi, tetapi juga bertanggungjawab pada kegiatan reproduksi.

Pada kegiatan sosial kemasyarakatan, keluarga mereka baik suami maupun istri samasama terlibat aktif dalam masyarakat. Kegiatan masyarakat yang diikuti antara lain, acara pernikahan, PKK/arisan, dan acara layatan. Meskipun suami dan istri sama-sama terlibat dalam kegiatan masyarakat, terdapat pembedaan antara suami dan istri terhadap kegiatan tersebut. Dalam kegiatan pernikahan perempuan lebih dilibatkan dalam rewang, sedangkan suami tidak. Dalam kegiatan arisan suami maupun istri sama-sama terlibat, namun kegiatan keduanya terpisah. Ada arisan khusus bapak-bapak dan arisan khusus ibu-ibu atau PKK, sehingga suami pergi sendiri tanpa didampingi istri sementara istri juga sebaliknya. Menurut mereka bahwa arisan bapak-bapak biasanya juga membahas tentang kerja bakti, kebersihan kampung dan pembangunan jalan. Sedangkan pada arisan ibu-ibu atau PKK, membahas tentang hal-hal yang berkaitan dengan aktivitas reproduksi seperti kesehatan balita atau anak. Hal tersebut semakin meneguhkan bahwa aktivitas laki-laki masih dianggap sebagai aktivitas yang bersifat pada ranah publik sedangkan aktivitas perempuan masih bersifat reproduktif. Begitu pula dengan kegiatan kerja bakti, dalam hal ini lebih banyak dilakukan oleh suami, keterlibatan istri hanya sebatas menyediakan makanan bagi para suami yang mengikuti kerja bakti. Sedangkan pada kegiatan layatan suami maupun istri sama-sama terlibat.

Sehingga dapat disimpulkan bahwa dalam kegiatan sosial kemasyarakatan, keluarga mereka baik suami maupun istri sama-sama terlibat aktif dalam masyarakat. Meskipun keterlibatan baik suami maupun istri masih dipengaruhi oleh peran gender yang masih melekatkan pada jenis kelamin tertentu seperti peran pada ranah publik seperti tentang kerja bakti, kebersihan kampung dan pembangunan jalan dilekatkan pada laki-laki sedangkan perempuan masih dilekatkan pada kegiatan kemasyarakatan yang membahas hal-hal yang sifatnya reproduktif seperti kesehatan balita atau anak karena sifat perempuan yang dianggap cocok terhadap hal-hal pemeliharaan.

Dari keterangan di atas dapat disimpulkan bahwa pembedaan antara perempuan dan laki-laki dalam kegiatan kemasyarakatan tersebut semakin meneguhkan bahwa aktivitas lakilaki masih dianggap sebagai aktivitas yang berorientasi pada ranah publik sedangkan aktivitas perempuan masih berkenaan dengan hal-hal reproduktif. Hal ini disebabkan karena kegiatan sosial laki-laki, seperti kerja bakti, pembangunan jalan lekat dengan kegiatan yang memerlukan kekuatan fisik dan energi yang besar. Sedangkan kegiatan sosial perempuan lekat dengan aktivitas pengasuhan, pemeliharaan seperti sosialisasi tentang kesehatan anak balita.

Akibatnya perempuan yang tidak dilibatkan akan berdampak pada minimnya informasi mengenai kegiatan pada ranah publik seperti kerja bakti, pembangunan jalan tersebut. Begitu pula dengan laki-laki yang tidak dilibatkan pula pada kegiatan pengasuhan, pemeliharaan seperti sosialisai tentang kesehatan anak balita juga tidak mengetahui informasi tersebut. Pada dasarnya kegiatan keduanya sebenarnya penting untuk diketahui baik bagi 
perempuan dan laki-laki. Namun, untuk mengatasi hal tersebut dalam keluarga ini mentranformasikan pengetahuan masing-masing mengenai kegiatannya di dalam keluarga. Hal tersebut bertujuan agar kedua-duanya mengetahui mengenai kegiatan masing-masing baik dari perempuan dan laki-laki.

\section{Pembagian Akses Kontrol di dalam Keluarga Perempuan Ojek Online di Surakarta}

Profil Akses dan kontrol ini merinci sumber-sumber apa yang dikuasai laki-laki dan perempuan untuk melaksanakan kegiatannya dan manfaat apa yang diperoleh setiap orang dari hasil kegiatan tersebut. Profil ini memperlihatkan siapa yang memiliki akses terhadap sumber daya dan kontrol atas penggunaannya. Kemudian diidentifikasi, disusun dalam daftar apakah perempuan dan laki-laki mempunyai akses atau tidak terhadap sumber daya dan kontrol atas penggunaannya. Orang yang mengontrol sumberdaya adalah orang yang pada akhirnya dapat membuat keputusan mengenai penggunaan sumberdaya tersebut: bagaimana sumberdaya itu akan digunakan, apakah sumberdaya itu dapat dijual, dan lain-lain. (Oxfam untuk Gender Learning Team, 1995). Sumberdaya yang akan dipaparkan dibawah antara lain berasal dari pendapatan suami, pendapatan istri, kendaraan bermotor, tanah, rumah, dan tabungan.

Dalam hal ini suami lebih memiliki kontrol terhadap tanah dan rumah. Hal tersebut didasarkan pada suami karena dengan alasan bahwa tanah dan rumah pada awalnya adalah warisan dari orangtua suami, kepemilikan suami dan suami sebagai kepala keluarga. Namun meskipun pengatanamaan tanah dan rumah pada suami, tidak lantas membuat suami yang memiliki kontrol penuh atas tanah dan rumah. Hal tersebut dikarenakan bahwa jika tanah dan rumah akan dijual harus juga mendapat persetujuan istri dengan tanda tangan sah. Sehingga dapat dikatakan bahwa pengambilan keputusan tetap berada pada keduanya, yaitu antara suami dan istri.

Terkait kontrol mengenai tabungan dan kendaraan dilakukan masing-masing baik istri maupun suami, karena kepemilikan tabungan kendaraan tersebut dimiliki oleh masingmasing antara suami dan istri. Sedangkan mengenai pendapatan lebih dikontrol oleh istri, karena dengan alasan bahwa yang mengatur uang di dalam keluarga ialah istri. Ini memperlihatkan bahwa mengenai akses kontrol dalam keluarga perempuan ojek online, kini akses-kontrol lebih banyak diperankan oleh perempuan atau istri. Pendapatan istri yang lebih besar daripada suami mengimplikasikan bahwa perempuan memiliki akses dan kontrol terhadap pendapatannya sendiri tanpa campur tangan suami.

Dengan diperolehnya penghasilan sendiri kini para istri tersebut juga bebas memanfaatkan penghasilan mereka untuk keperluan pribadi mereka sendiri. Seperti kebutuhan ke salon, biaya kecantikan, berbelanja pakaian dan berbagai kebutuhan kesenangan lainnya. Para suami tidak mengontrol pengeluaran istri karena mereka berpikiran bahwa uang yang digunakan merupakan penghasilan istri sendiri. Namun, berbeda halnya dengan suami meskipun pendapatannya lebih sedikit daripada istri terdapat anggapan bahwa suami wajib menafkai istri dan keluarga, sehingga hal tersebut mengimplikasian pendapatan suami juga diakses dan dikontrol oleh istri. Mengenai anggapan tersebut dapat dikatakan bahwa budaya patriarkhi masih mengakar kuat di dalam pembagian kerja terhadap akseskontrol pendapatan suami.

Dari berbagai uraian di atas untuk lebih jelasnya akan diringkas di dalam tabel di bawah ini, pada tabel di bawah dapat diketahui bahwa istri dan suami mengambil porsi yang sama dalam kegiatan produksi. Namun, suami sebagai pencari nafkah utama sedangkan istri sebagai pencari nafkah tambahan. Sedangkan pada kegiatan reproduksi, pembagian kerja yang ada tidak dibedakan berdasarkan jenis kelamin, setiap orang/individu memiliki 
kewajiban yang sama besarnya dalam aktivitas reproduksi. Meskipun dalam hal ini sudah ada partisipasi laki-laki, tetapi tetap porsi perempuan lebih besar daripada laki-laki dalam kegiatan reproduksi ini. Pada kegiatan sosial kemasyarakatan suami lebih dilibatkan pada urusan yang menyangkut publik. Sedangkan istri dilibatkan pada urusan yang menyangkut kegiatan reproduktif. Pada pembagian akses dan kontrol terhadap sumber daya yang dimiliki oleh keluarga perempuan ojek online menunjukkan akses terhadap sumber daya dapat dilakukan oleh semua anggota keluarga, namun pada kontrol terhadap sumber daya tersebut lebih banyak dilakukan oleh istri.

Tabel Matriks Pembahasan Profil Pembagian Aktivitas Produksi, Reproduksi, Sosial Kemasyarakatan dan Profil Akses dan Kontrol/Manfaat

\begin{tabular}{|l|l|}
\hline \multicolumn{1}{|c|}{ Profil } & \multicolumn{1}{|c|}{ Keterangan } \\
\hline Aktivitas Produksi & $\begin{array}{l}\text { Terdapat pembagian kerja antara suami dan istri, } \\
\text { namun suami sebagai pencari nafkah utama } \\
\text { sedangkan istri sebagai pencari nafkah tambahan. }\end{array}$ \\
\hline Aktivitas Reproduksi & $\begin{array}{l}\text { Pembagian kerja yang ada tidak dibedakan } \\
\text { berdasarkan jenis kelamin, setiap orang/individu } \\
\text { memiliki kewajiban yang sama besarnya dalam } \\
\text { aktivitas reproduksi. Meskipun sudah ada partisipasi } \\
\text { laki-laki, namun porsi perempuan lebih besar } \\
\text { daripada laki-laki dalam kegiatan reproduksi ini. }\end{array}$ \\
\hline Kegiatan Sosial & $\begin{array}{l}\text { Suami lebih dilibatkan pada kegiatan yang } \\
\text { Kenyangkut urusan publik. Sedangkan istri } \\
\text { dilibatkan pada urusan yang menyangkut kegiatan } \\
\text { reproduktif. }\end{array}$ \\
\hline Akses dan Kontrol & $\begin{array}{l}\text { Akses terhadap sumber daya dilakukan oleh semua } \\
\text { anggota keluarga, namun pada kontrol terhadap } \\
\text { sumber daya tersebut lebih banyak dilakukan oleh } \\
\text { istri. }\end{array}$ \\
\hline
\end{tabular}

Faktor-Faktor yang Mempengaruhi Pembagian Aktivitas, Akses dan Kontrol di dalam Keluarga Perempuan Ojek Online di Surakarta

Faktor-faktor yang berpengaruh terhadap aktivitas dan akses kontrol pada keluarga perempuan yang bekerja sebagai ojek online ialah faktor ekonomi, budaya dan pendidikan.

\section{Faktor Ekonomi}

Pengaruh faktor ekonomi ini ditunjukkan dengan adanya tingkat pendapatan keluarga yang kurang mencukupi. Pendapatan suami yang dirasa kurang untuk memenuhi kebutuhan sehari-hari, membuat istri ikut bekerja sebagai ojek online untuk menambah pendapatan. Keikutsertaan istri dengan bekerja ternyata berdampak positif terhadap pendapatan keluarga. Pendapatan yang diperoleh dari bekerja sebagai ojek online bisa dikatakan cukup tinggi, bahkan melebihi pendapatan suami. Sehingga pendapatan tersebut dirasa lebih dari cukup untuk memenuhi kebutuhan sehari-hari jika ditambahkan dengan pendapatan suami. Hal tersebut dapat dikatakan bahwa faktor ekonomi mempengaruhi pembagian kerja di dalam keluarga tersebut, yaitu pada aktivitas produksi yang tidak hanya dikerjakan suami, tetapi juga istri.

Namun bekerja sebagai ojek online setidaknya dilakukan istri dari pagi hingga sore, bahkan terkadang hingga malam. Hal tersebut tentu mempengaruhi pekerjaan domestik yang 
sebelumnya banyak dikerjakan oleh istri. Setelah keikutsertaan istri bekerja, nampaknya suami juga ikut melakukan pekerjaan domestik. Hal itu dilakukan suami karena memaklumi kesibukan istri yang bekerja hingga malam, mengingat tujuan bekerja adalah untuk memperoleh pendapatan keluarga. Tingkat pendapatan istri yang lebih tinggi dibandingkan suami juga mempengaruhi pembagian akses dan kontrol dalam keluarga. Hal ini ditunjukkan dengan adanya kendali oleh istri sendiri terhadap pendapatannya, tabungan, dan kepemilikan kendaraan. Selain itu suami tidak terlibat dalam pengelolaan pendapatan atau tabungan yang dimiliki istri. Sehingga hal tersebut dapat dikatakan bahwa faktor ekonomi dapat mempengaruhi aktivitas, akses dan kontrol di dalam keluarga.

\section{Budaya Patriarkhi}

Pengaruh budaya patriarkhi dibuktikan dengan adanya anggapan bahwa suami adalah kepala keluarga, sehingga suamilah yang dianggap wajib bertanggungjawab dalam mencari nafkah, untuk memenuhi kebutuhan sehari-hari. Istri dianggap tidak wajib untuk mencari nafkah, namun jika itu kemauan istri sendiri suami tetap mengijinkan. Meskipun sudah ada kesetaraan perempuan dalam aktivitas produksi dengan bekerja sebagai ojek online, namun di dalam aktivitas reproduksi seperti memasak dan mengasuh anak, tetap istri yang lebih banyak bertanggungjawab melakukan aktivitas tersebut. Hal ini karena adanya sifat keibuan yang melekat pada ibu yang bekerja, dengan mau mengalah dan berkorban demi memprioritaskan keluarga. Bagi mereka pekerjaan tidak membatasi mereka untuk bertanggungjawab dalam pengasuhan keluarga.

\section{Faktor Pendidikan}

Pengaruh pendidikan ini ditunjukkan dengan adanya tingkat kemampuan atau pendidikan istri yang lebih tinggi daripada suami. Hal tersebut mengindikasikan bahwa perempuan memiliki potensi yang lebih besar dalam mengakses pengetahuan dan teknologi dibandingkan suami, yang mana teknologi tersebut dapat dijadikan alat sumber daya ekonomi. Sehingga faktor pendidikan ini dapat dikatakan berpengaruh pada pembagian aktivitas, dan akses-kontrol terhadap sumber daya ekonomi di dalam keluarga.

Menurut teori Struktur Fungsional oleh Talcott Parson, dalam konteks relasi gender, pembagian peran secara seksual adalah wajar. Suami mengambil peran instrumental, membantu memelihara sendi-sendi masyarakat dan keutuhan fisik keluarga dengan jalan menyediakan bahan makanan, tempat pelindungan dan menjadi penghubung keluarga dengan dunia luar, the world outside the home. Sementara istri mengambil peran ekspresif membantu mengentalkan hubungan, memberikan dukungan emosional dan pembinaan kualitas yang menopang keutuhan keluarga serta menjamin kelancaran urusan rumah tangga. Menurut teori ini, jika terjadi tumpang tindih dan penyimpangan fungsi antara satu dan lainya, maka sistem keutuhan keluarga akan mengalami ketidakseimbangan. Dengan kata lain kerancuan peran gender akan mengakibatkan ketidakharmonisan dalam rumahtangga, atau bahkan perceraian. Keseimbangan akan menciptakan sebuah sistem sosial yang tertib (social order) (Bales, 1976 : 66). Namun hal yang terjadi pada keluarga perempuan ojek online, meskipun kini istri mulai terlibat di sektor publik dengan bekerja sebagai ojek online, namun sistem atau keharmonisan keluarga dapat berjalan dengan baik. Hal tersebut terjadi karena adanya konsensus di dalam anggota keluarga. Suami mereka pun menyadari bahwa istri yang sebelumnya dikonstruksikan sebagai ibu rumah tangga tetapi juga dapat berperan aktif dalam aktivitas produksi dengan bekerja di sektor publik. Mengingat tujuan dari istri tersebut bekerja adalah demi menambah pendapatan keluarga demi keberlangsungan hidup, sehingga 
tidak menjadi masalah apabila para suami tersebut juga harus bertukar peran dengan mengerjakan aktivitas domestik atau rumah tangga. Selain itu, untuk mengerjakan aktivitas domestik atau reproduksi tidak hanya dilakukan oleh suami dan istri namun tampak keterlibatan setiap individu di dalam keluarga, yaitu anak-anak. Setiap individu di dalam keluarga memiliki tanggung jawab dalam pekerjaan reproduksi tanpa membeda-bedakan antara perempuan dan laki-laki. Sehingga yang terjadi adalah keharmonisan di dalam keluarga yang mana setiap anggota saling menghormati dan memenuhi hak setiap individu di dalam keluarga.

Hal ini sesuai dengan pandangan Talcott Parson bahwa harmoni dan stabilitas dalam keluarga, menurut teori fungsional stuktural sangat ditentukan oleh efektifitas konsensus nilai-nilai. Sistem ini senantiasa bekerja dan berfungsi untuk menciptakan keseimbangan (equilibrium). Meskipun konflik sewaktu-waktu bisa muncul tetap dalam batas yang wajar dan bukan merupakan ancaman yang bakal merusak sistem sosial. Dalam pandangan Parson, ketertiban akan tercipta kalau ada struktur atau strata dalam keluarga, dimana masing-masing individu mengetahui posisinya dan patuh pada sistem nilai yang melandasi struktur tersebut. Untuk mewujudkan keseimbangan tersebut maka tiga elemen utama dalam struktur internal keluarga harus saling terkait, antara lain: status sosial, peran sosial dan norma sosial (Bales, 1976 : 66). Berdasarkan status sosial, keluarga dibagi dalam tiga struktur utama yaitu bapak/suami, ibu/istri dan anak-anak. Dalam struktur ini, masing- masing mempunyai status sosial yang memberikan identitas pada masing-masing individu. Karena dalam pandangan Parsons bahwa keharmonisan suatu masyarakat dapat tercapai apabila terdapat diferensiasi peran, dimana setiap individu akan mengetahui masing-masing posisinya dan patuh pada sistem nilai yang melandasinya. Parsons membagi dua peran orangtua dalam keluarga yaitu peran instrumental yang diharapkan dilakukan oleh suami, yaitu mencari nafkah dan peran ekspresif yang diharapkan dilakukan istri, yaitu peran pemberi cinta, kelembutan dan kasih sayang.

Hal tersebut terjadi pada keluarga perempuan ojek online, meskipun demikian teori tersebut tidak diterima sepenuhnya. Diferensiasi peran tidak hanya membagi peran menjadi dua yaitu peran instrumental dan peran ekspresif, namun juga terdapat diferensiasi peran pada keduanya. Yaitu pada kegiatan produksi atau instrumental, yaitu suami sebagai pencari nafkah utama sedangkan istri sebagai pencari nafkah tambahan. Sedangkan pada kegiatan reproduksi atau ekspresif tidak hanya dilakukan istri saja namun juga dilakukan oleh suami. Sehingga peran keduanya tidak terjadi secara kaku, artinya tukar peran antar keduanya dapat dilakukan. Hal tersebut terjadi karena keduanya sama-sama bersepakat dan saling menghormati peran masing-masing. Saling bertanggung jawab dalam memenuhi hak masingmasing individu. Karena masing-masing individu tersebut memiliki tujuan yang sama. Sehingga berdampak pada terciptanya kedamaian dan keharmonisan keluarga.

\section{KESIMPULAN}

Pada pembagian terhadap aktivitas produksi di dalam keluarga perempuan ojek online tersebut bahwa pembagian aktivitas produksi dilakukan bersama-sama. Baik suami maupun istri sama-sama bekerja dan saling bekerjasama untuk memperoleh pendapatan keluarga. Ini membuktikan bahwa terdapat kesempatan yang sama dalam hal aktivitas produksi karena keduanya baik suami maupun istri sama-sama melakukan aktivitas tersebut dan memiliki tujuan yang sama, yaitu memperoleh pendapatan di dalam keluarga. Namun terdapat diferensiasi peran yaitu suami sebagai pencari nafkah utama sedangkan istri sebagai pencari nafkah tambahan. Sedangkan pada kegiatan reproduksi, juga terdapat adanya pembagian kerja antara suami dan istri. Kegiatan reproduksi tidak hanya dilakukan oleh istri saja, tetapi 
juga suami. Meskipun demikian, kegiatan reproduksi ini masih banyak dilakukan istri. Selain itu, tiap anggota keluarga baik laki-laki maupun perempuan memiliki kewajiban yang sama dalam bertanggungjawab pada aktivitas reproduksi. Dalam kegiatan sosial kemasyarakatan, keluarga mereka baik suami maupun istri sama-sama terlibat aktif dalam masyarakat. Suami lebih dilibatkan pada kegiatan yang menyangkut urusan publik. Sedangkan istri dilibatkan pada urusan yang menyangkut kegiatan reproduktif.

Mengenai akses kontrol di dalam keluarga perempuan yang ojek online, kini akseskontrol lebih banyak diperankan oleh perempuan atau istri. Istri memiliki akses dan kontrol terhadap pendapatannya sendiri tanpa campur tangan suami. Meskipun dengan semakin mandirinya istri, atau dalam arti istri memiliki pendapatan sendiri, suami tetap memberikan penghasilannya kepada istri. Hal tersebut dikarenakan adanya anggapan bahwa suami berkewajiban dalam menafkai istri. Faktor-faktor yang berpengaruh terhadap pembagian aktivitas produksi disebabkan karena faktor ekonomi, pembagian aktivitas reproduksi disebabkan karena faktor sosialisasi keluarga, pembagian aktivitas dalam kegiatan kemasyarakatan disebabkan oleh faktor budaya yang dipengaruhi oleh keragaman biologis, dan pembagian akses kontrol pada keluarga perempuan yang bekerja sebagai ojek online disebabkan oleh budaya patriarkhi.

\section{DAFTAR PUSTAKA}

Abdullah, Irwan. 2001. Seks, Gender dan Reproduksi Kekuasaan. Yogyakarta: Tarawang Press

Anonim. 2017. Pengertian Ojek Online. https://suduthukum.com/2017/03/ojek-online.html. Diakses pada tanggal 23 Juli 2019

Badan Pusat Statistik. 2018. Tingkat Partisipasi Angkatan Kerja (TPAK) 2018

Badan Pusat Statistik. 2018. IPG (Indeks Pembangunan Gender) 2018

Demartoto, Argyo. 2007. Menyibak Sensitivitas Gender dalam Keluarga Difabel. Surakarta : UNS Press.

Fakih, M. 2006. Analisis Gender dan Transformasi Sosial. Yogyakarta: Pustaka Pelajar.

Intyre, J. Mc. 1966. The Structure Fungsional Approach to Family Study. New York: The Mcmillan Co

Kartodirdjo, Sartono. 1982. Pemikiran Dan Perkembangan Historiografi Indonesia Suatu Alternatif . Jakarta: Gramedia

Khairuddin H. 1997. Sosiologi Keluarga. Yogyakarta : Nurcahaya

Lina, Sudarwati. 2003. Wanita Dan Struktur Sosial ( Suatu Analisa Tentang Peran Ganda Wanita Indonesia). Fakultas Ilmu Sosial Dan Ilmu Politik Universitas Sumatera Utara

Parsons, Talcott dan Bales, R.F. 1956. Socialization and Interaction Process. London: Routledge, Kegan \& Paul

Matlin, M.W. 2004. The Psychology Of Women (5th Edition). Canada: Wadsworth.

Megawangi, R. 2001. Membiarkan Berbeda? Sudut Pandang Tentang Relasi. Gender. Bandung: Mizan Pustaka.

Milles dan Huberman. 1997. Analisis Data Kualitatif. Jakarta: Universitas Indonesia Press

Moleong, J Lexy. 2006. Metodologi Penelitian Kualitatif. Bandung: PT. Remaja Rosdakarya Nugroho, Riant. 2008. Gender dan Strategi Pengarus-Utamaannya di Indonesia. Yogyakarta: Pustaka Pelajar.

Oxfam untuk Gender Learning Team. 1995. Pisau Bedah Gender

Undang-Undang Perkawinan No.1 tahun 1974 